\title{
PENGUKURAN RISIKO PADA RETENSI OPTIMAL UNTUK REASURANSI STOP LOSS DENGAN VALUE AT RISK
}

\author{
Agustina Sunarwatiningsih $^{1}$, Yuciana Wilandari ${ }^{2}$, Agus Rusgiyono ${ }^{2}$ \\ ${ }^{1}$ Jurusan Matematika FMIPA Universitas Diponegoro \\ ${ }^{2}$ Staf Pengajar Program Studi Statistika FMIPA Universitas Diponegoro
}

\begin{abstract}
Reinsurance is an effective risk management tool for an insurer to minimize the risk of loss. Optimization criteria is based in a minimum VaR of the total risk of in insurer, to derive the optimal retention in stop loss reinsurance. The resulting optimal solution of optimization criterion has several important characteristics, such as: the optimal retention has a very simple analytic form; the optimal retention depends only on the assumed loss distribution and the reinsurer's loading factor; if optimal solution exist, then $V a R$ based optimization criteria yield the same optimal retentions; there exist a exceeds risk tolerance level which the insurer optimally should not reinsure her risks. The approach allows us to obtain different results of the optimization problem depends on the measurement of risk used. Furthermore, with optimal retention of risk measurement and minimum of $V a R$ to the total risk, the companies be able to minimize or reduce the loss ratio of claims own retention ceding company. One way to show the existence of an optimal retention used survival function distribution exponensial.
\end{abstract}

Key words: Stop Loss Reinsurance, Optimal Retention, Value at Risk (VaR)

\section{Pendahuluan}

Setiap perusahaan asuransi memiliki risiko terjadinya kerugian. Dalam upaya untuk mengatasi risiko tersebut, perusahaan dapat melakukan berbagai alternatif, yaitu dengan cara menanggung sendiri risiko, mengurangi risiko, memperkecil risiko atau mengalihkan risiko melalui asuransi. Oleh karena itu, perusahaan asuransi memerlukan kebijakan dalam mengelola risiko atas pertanggungan-pertanggungan yang diterimanya. Pada umumnya, perusahaan asuransi dalam mengelola risikonya dilakukan dengan cara membagi risiko yaitu mempertanggungkan kembali risiko yang tidak mungkin mereka tanggung sendiri kepada perusahaan asuransi lain sebagai penanggung ulang, yang disebut reasuransi. Jadi, reasuransi merupakan suatu mekanisme transfer risiko dari perusahaan asuransi kepada perusahaan asuransi yang lain sebagai penanggung ulang. Perusahaan yang mereasuransikan risikonya disebut ceding company atau asuradur. Sedangkan perusahaan asuransi yang menerima pertanggungan ulang dari ceding company disebut reasuradur.

Sama halnya dengan asuransi, reasuransi juga mengharuskan tertanggung untuk membayarkan premi kepada penanggung. Untuk itu diperlukan pembentukan reasuransi yang optimal bagi perusahaan asuransi dengan cara meminimalkan peluang kerugian perusahaan asuransi dari premi reasuransi. Reasuransi menyediakan peluang kepada perusahaan asuransi untuk mereduksi pertanggungan risiko dan lebih mengefektifkan managemen risiko. Diantara berbagai bentuk reasuransi yang ada, perjanjian Stop Loss merupakan solusi paling optimal yang dapat memperkecil nilai pertanggungan risiko perusahaan asuransi ${ }^{[1]}$.

Tingginya kebutuhan untuk mengukur risiko secara lebih tepat, menyebabkan banyaknya metode-metode pengukuran yang diusulkan, baik dari para peneliti maupun 
praktisi, seperti volatilitas, semivariance dan ecpected shortfall. Dari beberapa metode pengukuran risiko tersebut, hanya Value at Risk (VaR) yang paling banyak digunakan dalam pengukuran risiko, karena metode pengukuran ini dapat diaplikasikan ke seluruh produk-produk finansial yang diperdagangkan, angka yang didapatkan merupakan hasil perhitungan menyeluruh terhadap risiko produk-produk sebagai suatu kesatuan. Hal ini lebih praktis daripada metode-metode perhitungan lainnya, yang harus diaplikasikan secara individual pada masing-masing produk. VaR juga memberikan estimasi kemungkinan atau probabilitas mengenai timbulnya kerugian yang jumlahnya lebih besar daripada angka kerugian yang telah ditentukan. Selain itu VaR juga memperhatikan perubahan harga assetaset yang ada dan pengaruhnya terhadap aset-aset yang lain. Hal ini memungkinkan dilakukannya pengukuran terhadap berkurangnya risiko yang diakibatkan oleh diversifikasi kelompok produk ${ }^{[10]}$. Berdasarkan permasalahan tersebut, digunakan suatu konsep Value at Risk (VaR) dalam pengukuran nilai risiko untuk retensi optimal pada salah satu jenis reasuransi yaitu Reasuransi Stop Loss ${ }^{[6]}$.

\section{Konsep Dasar}

\subsection{Retensi Optimal}

Retensi Optimal adalah batas nilai yang paling efektif yang dapat dicapai dari kewajiban perusahaan asuransi berupa jumlah tertentu yang mana jumlah tersebut ditahan sendiri oleh perusahaan asuransi dan sisanya akan direasuransikan. Retensi ini adalah jumlah yang ditahan untuk tiap kerugian (single loss). Tujuan utama dari retensi adalah membantu mencapai stabilitas pengembangan perusahaan asuransi dan untuk menghindari tingkat fluktuasi yang besar dari suatu polis.

R. L. Carter dalam buku Hukum Asuransi dan Perusahaan Asuransi ${ }^{[2]}$ mengemukakan bahwa tidak ada satu metode teoritis yang dapat menentukan besarnya retensi bagi perusahaan asuransi. Oleh karena itu, baik untuk reasuransi proporsional maupun non proporsional cenderung dilakukan berdasarkan kebiasaan semata. Charter juga mengemukakan bahwa terdapat suatu hubungan antara "usaha" perusahaan (asuransi) dan jumlah kerugian yang dapat ditahan atas suatu risiko tertentu atau kelompok risiko tertentu dari suatu peristiwa dalam satu tahun tertentu.

\subsection{Retensi Optimal Pada Reasuransi Stop Loss}

Misalkan X jumlah kerugian pada perusahaan asuransi. Diasumsikan X adalah variabel random non negatif dengan fungsi distribusi kumulatif:

$$
F_{X}(x)=\mathrm{P}_{\mathrm{r}}\{X \leq x\},
$$

fungsi survival:

$$
S_{X}(x)=\mathrm{P}_{\mathrm{r}}\{X>x\} \text {, dan mean } \mathrm{E}[\mathrm{X}]>0 .
$$

$X_{I}$ dan $X_{r}$ adalah variabel random dari asuradur dan reasuradur pada reasuransi stop loss, sehingga:

atau

$$
X_{I}=\left\{\begin{array}{l}
X, X \leq R \\
R, X>R
\end{array}\right.
$$

dan

$$
\begin{aligned}
X_{I} & =X \Lambda R \\
& =\min \{X, R)
\end{aligned}
$$

$$
X_{r}= \begin{cases}0, & X \leq R \\ X-R, & X>R\end{cases}
$$

atau

$$
\begin{aligned}
X_{r} & =(X-R)_{+} \\
& =\operatorname{maks}\{X-R, 0\}
\end{aligned}
$$


dengan $R>0$ merupakan retensi.

Dalam perjanjian stop loss, reasuradur membayar jumlah kerugian asuradur yang melebihi batas retensi. Hal ini berarti reasuradur menanggung risiko yang melebihi batas retensi sedangkan secara efektif asuradur terlindungi dari potensial kerugian yang besar oleh batas pertanggungjawaban pada tingkat retensi. Reasuradur menerima premi reasuransi dalam setiap pembagian risiko. Salah satu prinsip premi yang biasa digunakan untuk menentukan tingkat premi adalah prinsip nilai perkiraan dimana premi reasuransi:

$$
\delta(R)=(1+\rho) \pi(R)
$$

dengan $\delta(R)$ merupakan premi reasuransi dan $\rho>0$ merupakan loading.

$$
\begin{aligned}
& \pi(R)=\mathrm{E}\left[\mathrm{X}_{\mathrm{r}}\right]=\mathrm{E}\left[(X-R)_{+}\right] \\
& =\int_{R}^{\infty}(x-R) f_{X}(x) d x \\
& \left.=-(x-R)\left(1-F_{X}(x)\right\rfloor_{R}^{\infty}\right)+\int_{R}^{\infty}\left(1-F_{X}(x)\right) d x \\
& =\int_{R}^{\infty}\left(1-F_{X}(x)\right) d x \\
& =\int_{R}^{\infty} S_{X}(x) d x
\end{aligned}
$$

dengan $\pi(R)$ adalah premi bersih stop loss ${ }^{[7]}$.

Diasumsikan $\mathrm{T}$ merupakan persentase total risiko atau total biaya asuradur pada reasuransi stop loss. Total risiko $\mathrm{T}$ dibentuk oleh dua komponen yaitu tanggungan kerugian dan premi reasuransi, sebagai berikut:

$$
T=X_{I}+\delta(R)
$$

Seandainya retensi $\mathrm{R}$ kecil, maka penahanan pertanggungan asuradur menjadi lebih rendah tetapi biaya premi yang harus dibayar kepada reasuradur lebih tinggi. Jika asuradur mereduksi biaya premi reasuransi dengan meningkatkan retensi, maka pertanggungan asuradur semakin besar ${ }^{[1]}$.

\subsection{Kriteria Optimisasi Berdasarkan Value At Risk}

Optimasi ialah suatu proses untuk mencapai hasil yang ideal atau optimal (nilai efektif yang dapat dicapai), yaitu untuk mencari nilai minimal atau maksimal dari suatu fungsi riil.

Manajemen risiko menunjukkan bahwa pengukuran risiko berhubungan dengan total risiko (T). Salah satu kriteria optimasi untuk mencari tingkat retensi optimal adalah menentukan pendekatan retensi optimal $\left(R^{*}\right)$ dengan mencari nilai minimal dari VaR sebagi berikut:

Optimasi VaR : $\operatorname{VaR}_{T}\left(R^{*}, \alpha\right)=\min _{R>0}\left\{\operatorname{VaR}_{T}(R, \alpha)\right\}$,

Hasil retensi optimal $\mathrm{R}^{*}$ menunjukkan bahwa $\operatorname{VaR}$ dari total risiko diminimalisasi untuk memberikan toleransi pada tingkat risiko ${ }^{[1]}$. 


\section{Hasil dan Pembahasan}

\subsection{Retensi Optimal Pada Optimasi Value At Risk}

Hal pertama yang harus diperhatikan dalam analisis solusi optimal pada optimasi $\mathrm{VaR}$ (5) adalah fungsi survival yang digunakan pada tanggungan kerugian $X_{I}$ sebagai berikut:

$$
S_{X_{I}}(x)=\left\{\begin{array}{c}
S_{X}(x), 0 \leq x<R \\
0, x \geq R
\end{array}\right.
$$

Dari persamaan (6), jika $0<\alpha \leq S_{X}(R)$ atau ekuivalen $0<R \leq S_{X}^{-1}(\alpha)$, maka $\operatorname{VaR}_{\mathrm{X}_{\mathrm{I}}}(R, \alpha)=R ; \quad$ jika $\quad \alpha>S_{X}(R) \quad$ atau ekuivalen $\quad R>S_{X}^{-1}(\alpha), \quad$ maka $\operatorname{VaR}_{\mathrm{X}_{\mathrm{I}}}(R, \alpha)=S_{X}^{-1}(\alpha)$. Sehingga $\operatorname{VaR}$ dari tanggungan kerugian $X_{I}$ adalah:

$$
\operatorname{VaR}_{X_{I}}(R, \alpha)=\left\{\begin{array}{l}
R, \quad 0<R \leq S_{X}^{-1}(\alpha) \\
S_{X}^{-1}(\alpha), R>S_{X}^{-1}(\alpha)
\end{array}\right.
$$

Dengan $T=X_{I}+\delta(R)$, maka hubungan antara VaR pada total risiko dan VaR pada tanggungan kerugian sebagai berikut:

$$
\operatorname{VaR}_{T}(R, \alpha)=\operatorname{VaR}_{X_{I}}(R, \alpha)+\delta(R)
$$

$\operatorname{VaR}_{X_{I}}(R, \alpha)$ merupakan suatu fungsi naik dari $\mathrm{R}$, sementara $\delta(R)$ merupakan fungsi turun dari R. Dengan mensubtitusikan persamaan (7) ke (8) diperoleh bentuk $\operatorname{VaR}_{T}(\mathrm{R}, \alpha)$.

\section{Proposisi $1^{[1]}$}

Untuk setiap $R>0$ dan $0<\alpha<S_{X}(0)$,

$$
\operatorname{VaR}_{T}(R, \alpha)=\left\{\begin{array}{c}
R+\delta(R), \quad 0<R \leq S_{X}^{-1}(\alpha), \\
S_{X}^{-1}(\alpha)+\delta(R), R>S_{X}^{-1}(\alpha)
\end{array}\right.
$$

Didefinisikan : $\quad \rho^{*}=\frac{1}{1+\rho}$

$\rho^{*}$ merupakan loading optimal, yang memiliki peranan penting dalam solusi kriteria optimasi.

Teorema yang menyatakan perlu adanya retensi optimal pada optimasi berdasarkan VaR pada persamaan (5) adalah sebagai berikut:

\section{Teorema $1^{[1]}$}

a) Retensi optimal $R^{*}>0$ pada persamaan (5) ada jika dan hanya jika

$$
\alpha<\rho^{*}<S_{X}(0)
$$
dan

$$
S_{X}^{-1}(\alpha) \geq S_{X}^{-1}\left(\rho^{*}\right)+\delta\left(S_{X}^{-1}\left(\rho^{*}\right)\right)
$$

berlaku.

b) Jika retensi optimal $R^{*}$ pada persamaan (5) ada, maka

$$
R^{*}=S_{X}^{-1}\left(\rho^{*}\right)
$$

dan VaR minimal dari Total risiko adalah :

$$
\operatorname{VaR}_{T}\left(\mathrm{R}^{*}, \alpha\right)=R^{*}+\delta\left(R^{*}\right)
$$

\section{Bukti:}

a) Diketahui (i) $\alpha<\rho^{*}<S_{X}(0)$

$$
\text { (ii) } S_{X}^{-1}(\alpha) \geq S_{X}^{-1}\left(\rho^{*}\right)+\delta\left(S_{X}^{-1}\left(\rho^{*}\right)\right)
$$

Akan dibuktikan $R^{*}=S_{X}^{-1}\left(\rho^{*}\right)>0$ 
Dari persamaan (9) yaitu

$$
\operatorname{VaR}_{T}(R, \alpha)=\left\{\begin{aligned}
R+\delta(R), & 0<R \leq S_{X}^{-1}(\alpha), \\
S_{X}^{-1}(\alpha)+\delta(R), & R>S_{X}^{-1}(\alpha),
\end{aligned}\right.
$$

dapat diketahui bahwa $\operatorname{VaR}_{T}(\mathrm{R}, \alpha)$ kontinu di $R \in(0, \infty)$ dan turun di $R \in\left(S_{X}^{-1}(\alpha), \infty\right)$.

Dengan $R_{0}=S_{X}^{-1}\left(\rho^{*}\right)>0$, fungsi $R+\delta(R)$ turun di $R \in\left(0, R_{0}\right)$ dan naik di $R \in\left(R_{0}, S_{X}^{-1}(\alpha)\right)$. Fungsi $R+\delta(R)$ mencapai nilai minimumnya pada $R_{0}$ dengan nilai minimum $R_{0}+\delta\left(R_{0}\right)$

Oleh karena itu, persamaan (11) yaitu:

menjadi

$$
S_{X}^{-1}(\alpha) \geq S_{X}^{-1}\left(\rho^{*}\right)+\delta\left(S_{X}^{-1}\left(\rho^{*}\right)\right)
$$

Sebagai konsekuensinya,

$$
S_{X}^{-1}(\alpha) \geq R_{0}+\delta\left(R_{0}\right)
$$

jika $\alpha<\rho^{*}<S_{X}(0)$ dan $S_{X}^{-1}(\alpha) \geq S_{X}^{-1}\left(\rho^{*}\right)+\delta\left(S_{X}^{-1}\left(\rho^{*}\right)\right)$ berlaku, maka $0<R_{0}<S_{X}^{-1}(\alpha)$ dan nilai minimum $\operatorname{VaR}_{T}(R, \alpha)=R_{0}+\delta\left(R_{0}\right)$.

Oleh karena itu, $R_{0}>0$ merupakan retensi optimal. Sehingga, $R_{0}=R^{*}$. Hal ini dapat dilihat dari grafik $\operatorname{VaR}_{T}(R, \alpha)$ pada Gambar 1 .

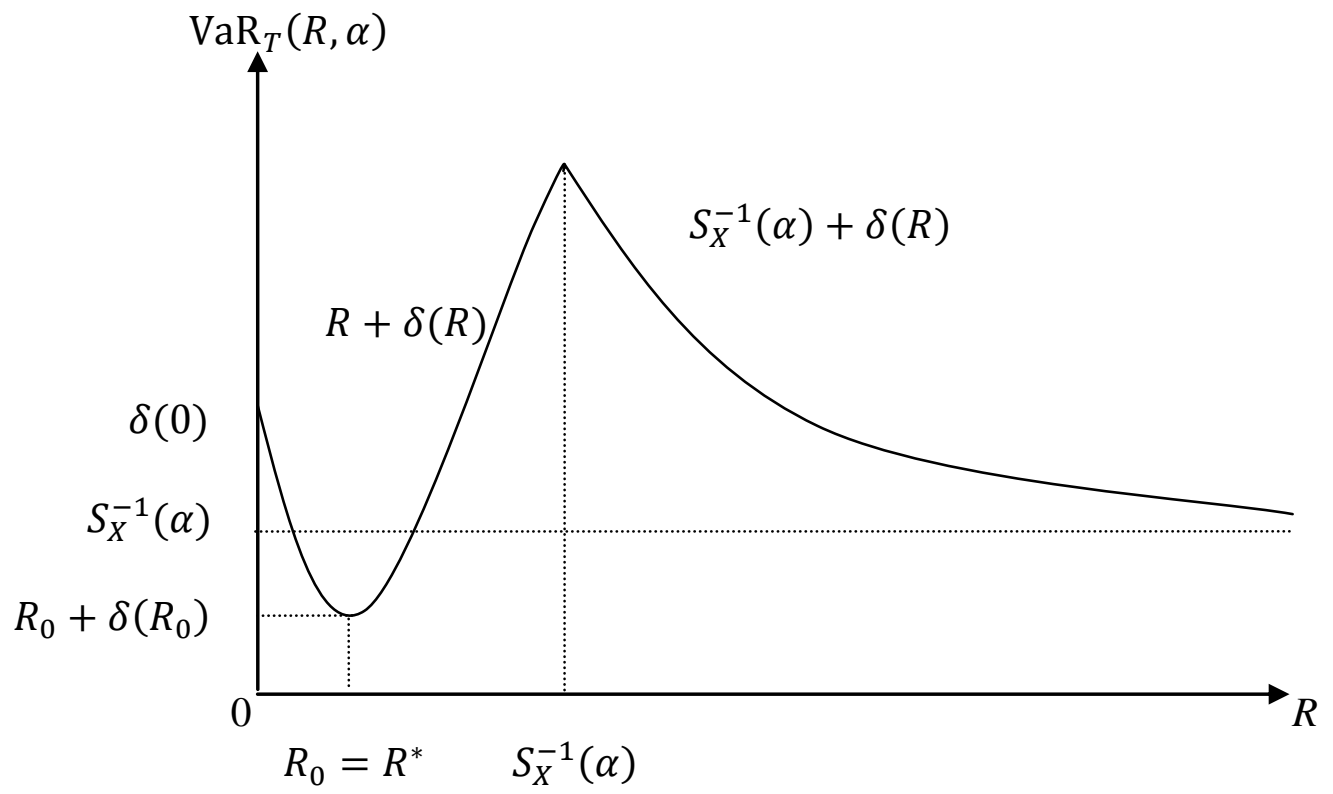

Gambar 1. Tipe Grafik dari $\operatorname{VaR}_{T}(R, \alpha)$

Diketahui $R^{*}=S_{X}^{-1}\left(\rho^{*}\right)>0$
Akan dibuktikan
(i) $\alpha<\rho^{*}<S_{X}(0)$
(ii) $S_{X}^{-1}(\alpha) \geq S_{X}^{-1}\left(\rho^{*}\right)+\delta\left(S_{X}^{-1}\left(\rho^{*}\right)\right)$

Untuk membuktikan jika diketahui $R^{*}=S_{X}^{-1}\left(\rho^{*}\right)>0$

maka (i) $\alpha<\rho^{*}<S_{X}(0)$

(ii) $S_{X}^{-1}(\alpha) \geq S_{X}^{-1}\left(\rho^{*}\right)+\delta\left(S_{X}^{-1}\left(\rho^{*}\right)\right)$

ekuivalen dengan membuktikan kontraposisinya yaitu:

Jika negasi $\left(\alpha<\rho^{*}<S_{X}(0)\right.$ dan $\left.S_{X}^{-1}(\alpha) \geq S_{X}^{-1}\left(\rho^{*}\right)+\delta\left(S_{X}^{-1}\left(\rho^{*}\right)\right)\right)$ berlaku, maka negasi $\left(R^{*}=S_{X}^{-1}\left(\rho^{*}\right)>0\right)$ ada. 
Berarti akan dibuktikan jika (i) $\alpha<\rho^{*}<S_{X}(0)$

$$
\text { (ii) } S_{X}^{-1}(\alpha) \geq S_{X}^{-1}\left(\rho^{*}\right)+\delta\left(S_{X}^{-1}\left(\rho^{*}\right)\right)
$$

tidak berlaku, maka retensi optimal tidak ada.

Jika $\alpha<\rho^{*}<S_{X}(0)$ tidak berlaku, $\operatorname{VaR}_{T}(R, \alpha)$ turun di $R \in(0, \infty)$ dengan $\lim _{R \rightarrow \infty} \operatorname{VaR}_{T}(R, \alpha)=S_{X}^{-1}(\alpha)$. Sehingga, dari sini dapat diketahui bahwa retensi optimal tidak ada.

$\operatorname{VaR}_{T}(R, \alpha)$ kembali menurun di $R \in(0, \infty)$ dengan nilai $\lim _{R \rightarrow \infty} \operatorname{VaR}_{T}(R, \alpha)=S_{X}^{-1}(\alpha)$. Sehingga, dari sini dapat diketahui bahwa retensi optimal tidak ada.

Jika $\alpha<\rho^{*}<S_{X}(0)$ berlaku tapi $S_{X}^{-1}(\alpha) \geq S_{X}^{-1}\left(\rho^{*}\right)+\delta\left(S_{X}^{-1}\left(\rho^{*}\right)\right)$ tidak berlaku, maka

$$
\operatorname{Inf}_{\mathrm{R}>0} \operatorname{VaR}_{T}(R, \alpha)=S_{X}^{-1}(\alpha),
$$

demikian juga untuk $R^{*}>0, \operatorname{VaR}_{T}\left(R^{*}, \alpha\right)=S_{X}^{-1}(\alpha)$.

Oleh karena itu, $\alpha<\rho^{*}<S_{X}(0)$ dan $S_{X}^{-1}(\alpha) \geq S_{X}^{-1}\left(\rho^{*}\right)+\delta\left(S_{X}^{-1}\left(\rho^{*}\right)\right)$ sangat penting agar retensi optimal $R^{*}>0$ tetap ada.

b) Diketahui retensi optimal $R^{*}$ ada.

Akan dibuktikan $R^{*}=S_{X}^{-1}\left(\rho^{*}\right)$ dan $\operatorname{VaR}_{T}\left(R^{*}, \alpha\right)=R^{*}+\delta\left(R^{*}\right)$.

Karena retensi optimal ada $R^{*}>0$, dari bukti a) diperoleh $R^{*}=R_{0}$ sehingga nilai minimum $\operatorname{VaR}_{T}\left(R^{*}, \alpha\right)=R^{*}+\delta\left(R^{*}\right)$. Oleh karena itu, persamaan $R^{*}=S_{X}^{-1}\left(\rho^{*}\right)$ dan $\operatorname{VaR}_{T}\left(\mathrm{R}^{*}, \alpha\right)=R^{*}+\delta\left(R^{*}\right)$ berlaku.

\section{Akibat $1^{[1]}$}

Retensi optimal $R^{*}>0$ dalam persamaan (5) yaitu

$$
\operatorname{VaR}_{T}\left(R^{*}, \alpha\right)=\min _{R>0}\left\{\operatorname{VaR}_{T}(R, \alpha)\right\},
$$

ada jika persamaan (10) yaitu $\alpha<\rho^{*}<S_{X}(0)$ dan

berlaku.

$$
S_{X}^{-1}(\alpha) \geq(1+\rho) \mathrm{E}[\mathrm{X}]
$$

Retensi optimal $R^{*}$ dan VaR minimum, masing-masing diberikan oleh $R^{*}=S_{X}^{-1}\left(\rho^{*}\right)$ dan $\operatorname{VaR}_{T}\left(\mathrm{R}^{*}, \alpha\right)=R^{*}+\delta\left(R^{*}\right)$.

\section{Bukti :}

Diketahui $S_{X}^{-1}(\alpha) \geq(1+\rho) \mathrm{E}[\mathrm{X}]$.

Akan dibuktikan bahwa

Dari (14) diperoleh:

$$
\operatorname{VaR}_{T}\left(R^{*}, \alpha\right)=R^{*}+\delta\left(R^{*}\right) .
$$

$$
\begin{aligned}
& S_{X}^{-1}(\alpha) \geq(1+\rho) \mathrm{E}[\mathrm{X}] \\
& S_{X}^{-1}(\alpha) \geq(1+\rho)\left(\int_{0}^{R^{*}} S_{X}(x) d x+\int_{R^{*}}^{\infty} S_{X}(x) d x\right)
\end{aligned}
$$

Dengan $S_{X}\left(R^{*}\right)=S_{X}\left(S_{X}^{-1}\left(\rho^{*}\right)\right)=\rho^{*}$, (dari (12) $\left.R^{*}=S_{X}^{-1}\left(\rho^{*}\right)\right)$ sehingga (15) menjadi

$$
S_{X}^{-1}(\alpha) \geq(1+\rho)\left(\int_{0}^{s_{X}^{-1}\left(\rho^{*}\right)} S_{X}(x) d x+\int_{S_{X}^{-1}\left(\rho^{*}\right)}^{\infty} S_{X}(x) d x\right)
$$


Dari (3)

$$
\begin{aligned}
& S_{X}^{-1}(\alpha) \geq(1+\rho) \int_{0}^{S_{X}^{-1}\left(\rho^{*}\right)} S_{X}(x) d x+(1+\rho) \pi\left(S_{X}^{-1}\left(\rho^{*}\right)\right) \\
& S_{X}^{-1}(\alpha) \geq S_{X}^{-1}\left(\rho^{*}\right)+(1+\rho) \pi\left(S_{X}^{-1}\left(\rho^{*}\right)\right)
\end{aligned}
$$

Jadi, dari persamaan (16) terbukti bahwa:

$$
\begin{aligned}
S_{X}^{-1}(\alpha) & \geq S_{X}^{-1}\left(\rho^{*}\right)+\delta\left(S_{X}^{-1}\left(\rho^{*}\right)\right) \\
& \geq R^{*}+\delta\left(R^{*}\right) .
\end{aligned}
$$

Oleh karena terbukti bahwa $S_{X}^{-1}(\alpha) \geq(1+\rho) \mathrm{E}[\mathrm{X}]$ ekuivalen dengan

$S_{X}^{-1}(\alpha) \geq S_{X}^{-1}\left(\rho^{*}\right)+\delta\left(S_{X}^{-1}\left(\rho^{*}\right)\right)$, yang berarti sesuai dengan persamaan (10) dan (11) maka retensi optimal ada yaitu $R^{*}>0$.

Sesuai persamaan (5) $\operatorname{VaR}_{T}\left(R^{*}, \alpha\right)=\min _{R>0}\left\{\operatorname{VaR}_{T}(R, \alpha)\right\}$

menjadi

$$
\operatorname{VaR}_{T}\left(R^{*}, \alpha\right)=R^{*}+\delta\left(R^{*}\right)
$$

\subsection{Contoh Kasus}

Sebuah perusahaan asuransi, katakanlah asuransi PQR membina dan meningkatkan kerja sama dengan pihak reasuradur dalam rangka peningkatan kapasitas pertanggungan dengan penyebaran risiko kepada reasuradur dalam bentuk treaty. Salah satu merk kendaraan yang diasuransikan adalah Kendaraan "TOYOTA". Dalam melakukan perhitungan terhadap risiko kerugian perusahaan asuransi biasanya digunakan distribusi poisson atau distribusi eksponensial. Karena pada penerapan kasus ini menggunakan fungsi survival, sedangkan untuk distribusi poisson fungsi survivalnya tidak dapat diperoleh maka distribusi yang digunakan untuk menyelesaikan permasalahan dalam perhitungan risiko kerugian perusahaan asuransi ini adalah distribusi eksponensial, dengan fungsi survivalnya $S_{X}(x)=e^{-x / \beta}, x \geq 0$ dan $\beta>0$.

Jenis kendaraan yang akan dilakukan perhitungan merupakan jenis kendaraan non truck dengan usia kendaraan kurang dari 3 tahun. Sedangkan jenis asuransi yang akan digunakan adalah asuransi All Risk. Premi bersih yang berlaku di perusahaan PQR sesuai dengan Referensi Unsur Premi Murni serta Unsur Biaya Administrasi dan Umum Lainnya pada Lini Usaha Asuransi Kendaraan Bermotor Tahun 2008 - 2009. Dimisalkan premi bersih yang diterima perusahaan reasuransi hanya $20 \%$ dari premi bersih yang diterima perusahaan asuransi PQR. Periode waktu yang digunakan adalah 1 tahun $=525600$ menit. Diketahui masing-masing uang pertanggungan kendaraan bermotor, probabilitas toleransi risiko, rata-rata selang waktu terjadinya klaim dan faktor loading adalah sebagai berikut:

Tabel 1. Jenis Kendaraan, Uang Pertanggungan, Probabilitas Toleransi Risiko, Rata-Rata Selang Waktu Terjadinya Kerugian dan Faktor Loading ${ }^{[4]}$

\begin{tabular}{|c|l|c|c|c|c|}
\hline No. & Jenis Kendaraan & $\begin{array}{c}\text { Uang Pertanggungan } \\
(\mathbf{R p})\end{array}$ & $\boldsymbol{\alpha}$ & $\begin{array}{c}\mathbf{E}[\mathbf{X}]=\boldsymbol{\beta} \\
(\mathbf{m e n i t})\end{array}$ & $\begin{array}{c}\boldsymbol{\rho} \\
(\mathbf{\%})\end{array}$ \\
\hline 1. & Alphard & 806000000 & 0,1 & 357513 & 15 \\
\hline 2. & Camry & 647000000 & 0,05 & 279475 & 15 \\
\hline 3. & Fortuner & 470300000 & 0,1 & 234552 & 15 \\
\hline 4. & Corolla Altis & 375500000 & 0,05 & 357513 & 15 \\
\hline 5. & Hilux & 321700000 & 0,1 & 279475 & 15 \\
\hline 6. & Kijang Innova & 289100000 & 0,05 & 234552 & 10 \\
\hline 7. & All New Vios & 232200000 & 0,1 & 357513 & 10 \\
\hline 8. & Rush & 211300000 & 0,05 & 279475 & 10 \\
\hline 9. & Yaris & 214450000 & 0,1 & 234552 & 10 \\
\hline 10. & Avanza & 171000000 & 0,05 & 357513 & 10 \\
\hline
\end{tabular}


Fungsi densitas peluang distribusi eksponensial adalah sebagai berikut:

$$
f(x)=\frac{1}{\beta} e^{-x / \beta}, \quad x>0 \text { dan } \beta>0 .
$$

fungsi survival

$$
S_{X}(x)=e^{-x / \beta}=1
$$

Untuk menghitung nilai retensi optimal, maka harus dicari terlebih dahulu rumus dari $S_{X}^{-1}(x)$.

Jika diketahui $S_{X}(x)=e^{-x / \beta}$

$$
\text { maka } S_{X}^{-1}(x)=-\beta \ln x
$$

Sedangkan tarif premi pertanggungan baik Total Lost Only (TLO) maupun Comprehensive (All Risk) yang diterima perusahaan asuransi berdasarkan kategori kendaraan dan uang pertanggungan adalah sebagai berikut:

Tabel 2. Referensi Unsur Premi Murni serta Unsur Biaya Administrasi dan Umum Lainnya pada Lini Usaha Asuransi Kendaraan Bermotor Tahun 2008-2009 pada Usia Kendaraan Kurang Dari atau Sama Dengan 3 Tahun $^{[8]}$

\begin{tabular}{|c|c|c|c|}
\hline Kategori & Uang Pertanggungan & $\begin{array}{c}\text { Tarif Premi } \\
\text { Pertanggungan } \\
\text { Total Lost Only } \\
(\text { TLO) }\end{array}$ & $\begin{array}{c}\text { Tarif Premi } \\
\text { Pertanggungan } \\
\text { Comprehensive } \\
\text { (All Risk) }\end{array}$ \\
\hline Jenis Kendaraan Non Truck dan Non Bus \\
\hline Kategori 1 & 0 s.d Rp 150.000.000,00 & $0,47 \%$ & $2,05 \%$ \\
\hline Kategori 2 & Rp 150.000.000,00 - Rp 300.000.000,00 & $0,44 \%$ & $1,52 \%$ \\
\hline Kategori 3 & Rp 300.000.000,00 - Rp 500.000.000,00 & $0,42 \%$ & $1,17 \%$ \\
\hline Kategori 4 & Rp 500.000.000,00 - Rp 800.000.000,00 & $0,41 \%$ & $1,10 \%$ \\
\hline Kategori 5 & Lebih dari Rp 800.000.000,00 & $0,41 \%$ & $0,98 \%$ \\
\hline Jenis Kendaraan Truck dan Bus \\
\hline Kategori 6 & Truck, semua uang pertanggungan & $0,40 \%$ & $1,29 \%$ \\
\hline Kategori 7 & Bus, semua uang pertanggungan & $0,25 \%$ & $0,55 \%$ \\
\hline
\end{tabular}

Contoh penerapannya diberikan berikut ini:

Untuk kendaraan jenis “Alphard” dengan uang pertanggungan Rp 806.000.000,00; $\alpha=0,1$; maka sesuai dengan Referensi Unsur Premi Murni serta Unsur Biaya Administrasi dan Umum Lainnya pada Lini Usaha Asuransi Kendaraan Bermotor Tahun 2008 - 2009, premi bersih yang diterima perusahaan asuransi sebesar 0,98\% per tahun adalah Rp 7.898.800,00. Dimisalkan premi bersih yang diterima perusahaan reasuransi hanya $20 \%$ dari premi bersih yang diterima perusahaan asuransi $=\mathrm{Rp} 1.579 .760,00$. Jika diketahui rata-rata waktu selang terjdinya klaim $=357513$ menit; dan loading $=15 \%$; maka besarnya premi reasuransi diperoleh dari perhitungan sebagai berikut:

$$
\delta(R)=(1+\rho) \pi(R)=\operatorname{Rp} 1.816 .724,00
$$

Sedangkan loading optimalnya adalah:

$$
\rho^{*}=\frac{1}{(1+\rho)}=0,8696
$$

Jadi besarnya loading optimal adalah 0,8696 .

Nilai frekuensi kerusakan diperoleh dari pembagian dari satu periode waktu pembayaran premi dengan rata-rata waktu selang terjadinya kerusakan, sebagai berikut:

Frekuensi kerusakan $=525600 / 357513=1,470$.

Jadi, kendaraan tersebut memiliki frekuensi kerusakan 1,47 tiap tahun.

Misalkan biaya perbaikan dalam satu kali klaim adalah 5\% dari uang pertanggungan, maka nilai rata-rata biaya klaim per tahun diperoleh dari perkalian antara 
frekuensi kerusakan (seberapa sering terjadi kerusakan) dalam waktu satu tahun dengan biaya-biaya perbaikannya $=1,47 \times \operatorname{Rp} 40.300 .000,00=\operatorname{Rp} 59.247 .300,00$.

Sehingga, untuk perhitungan-perhitungan selanjutnya nilai $\beta$ yang digunakan adalah nilai rata-rata biaya klaim per tahun.

Untuk mengetahui adanya retensi optimal, ada 3 syarat yang harus dipenuhi yang terdapat dalam persamaan (10), (11) dan (14) sebagai berikut:

$$
\begin{aligned}
\text { i. } & \alpha<\rho^{*}<S_{X}(0) \\
\text { ii. } & S_{X}^{-1}(\alpha) \geq(1+\rho) \mathrm{E}[\mathrm{X}] \\
\text { iii. } & S_{X}^{-1}(\alpha) \geq S_{X}^{-1}\left(\rho^{*}\right)+\delta\left(S_{X}^{-1}\left(\rho^{*}\right)\right)
\end{aligned}
$$

- $\quad$ Syarat (i)

Dengan $\alpha=0,1$ maka dapat diketahui bahwa

$\alpha=0,1<\rho^{*}=0,8696<S_{X}(0)=1$

Sehingga syarat adanya optimal retensi pada persamaan (10), yaitu syarat (i) terpenuhi.

- Syarat (ii)

Untuk syarat yang kedua (ii), harus dicari terlebih dahulu nilai dari masing-masing $S_{X}^{-1}(\alpha)$ dan $(1+\rho) \mathrm{E}[\mathrm{X}]$.

Dengan fungsi densitas peluang distribusi eksponensial $f(x)=\frac{1}{\beta} e^{-x / \beta}$ dan fungsi survivalnya $S_{X}(x)=e^{-x / \beta}$, maka:

$$
\begin{aligned}
S_{X}^{-1}(\alpha) & =-\beta \ln \alpha \\
& =(-59247300) \times \ln (0,1) \\
& =136421950,01
\end{aligned}
$$

Jadi besarnya nilai risiko kerugian adalah Rp 136.421.950,01.

Sedangkan untuk nilai $(1+\rho) E[X]=(1+15 \%) \times 59247300$

$$
=68134395,11
$$

Sehingga, berdasarkan persamaan (14) syarat kedua adanya retensi optimal terpenuhi, yaitu $S_{X}^{-1}(\alpha)=136421950,01 \geq(1+\rho) \mathrm{E}[\mathrm{X}]$

$$
=68134395,11 \text {. }
$$

- $\quad$ Syarat (iii)

$$
\begin{aligned}
S_{X}^{-1}\left(\rho^{*}\right) & =-\beta \ln \left(\rho^{*}\right) \\
& =(-59247300) \times \ln (0,8696) \\
& =8280517,74
\end{aligned}
$$

Berdasarkan persamaan (11):

$$
\begin{aligned}
& S_{X}^{-1}(\alpha) \geq S_{X}^{-1}\left(\rho^{*}\right)+\delta\left(S_{X}^{-1}\left(\rho^{*}\right)\right) \\
& 136421950,01 \geq 8280517,74+1816724,00 \\
& 136421950,01 \geq 10097241,74
\end{aligned}
$$

Oleh karena ketiga syarat terpenuhi, maka dapat disimpulkan bahwa retensi optimal pada persamaan (5) ada. Sehingga, berdasarkan persamaan (12):

$$
R^{*}=S_{X}^{-1}\left(\rho^{*}\right)=8280517,74
$$

Jadi besarnya retensi optimal Rp 8.280.517,74

Sehingga diperoleh nilai minimal Total risiko berdasarkan persamaan (13) sebagai berikut:

$$
\begin{aligned}
\operatorname{VaR}_{T}(\mathrm{R}, \alpha) & =R^{*}+\delta\left(R^{*}\right) \\
& =\operatorname{Rp} 8.280 .517,74+\mathrm{Rp} \mathrm{1.816.724,00} \\
& =\mathrm{Rp} 10.097 .241,74 \\
\text { Risiko reasuransi } & =\text { rata-rata biaya klaim per tahun }-\mathrm{VaR}_{T}(\mathrm{R}, \alpha) \\
& =\operatorname{Rp} 59.247 .300,00-\mathrm{Rp} 10.097 .241,74 \\
& =\operatorname{Rp} 49.150 .058,36
\end{aligned}
$$


Jadi, dengan nilai pertanggungan Rp 806.000.000,00; rata-rata waktu selang klaim kendaraan yang terjadi adalah 357513 menit, loading 15\% dan frekuensi kerusakan 1,47 per tahun, diperoleh rata-rata biaya klaim per tahun sebesar Rp 59.247.300,00 dan retensi optimal sebesar Rp 8.280.517,74. Sehingga dengan premi bersih sebesar Rp 7.898.000,00 ada kemungkinan sebesar $1 \%$ bahwa total risiko yang ditanggung perusahaan asuransi sebesar Rp 10.097.241,74 atau lebih. Sedangkan, dengan premi bersih yang lebih rendah dari perusahaan asuransi yaitu sebesar $\mathrm{Rp} 1.579 .760,00$ perusahaan reasuransi akan menerima tanggungan beban risiko lebih besar dari total risiko yang ditanggung perusahaan asuransi yaitu maksimal sebesar Rp 49.150.058,36.

\section{Kesimpulan}

Dari analisis-analisis yang telah dilakukan, dapat disimpulkan bahwa:

a. Ada hubungan antara retensi optimal dengan VaR dimana nilai retensi optimal dapat ditentukan dengan nilai $V a R$ terkecil dari total risiko.

b. Perhitungan nilai retensi optimal dan nilai risiko pada reasuransi stop loss dengan $V a R$ harus berdasarkan pada nilai rata-rata biaya klaim per tahun, probabilitas toleransi risiko dan faktor loading, serta biaya preminya.

c. Tanggung jawab perusahaan asuransi dibatasi oleh besarnya retensi optimal, sedangkan besar tanggung jawab perusahaan reasuransi diperoleh berdasarkan nilai retensi optimalnya. Dari analisis kasus asuransi kendaraan "TOYOTA", perjanjian stop loss dapat memperkecil nilai risiko atau tanggungan perusahaan asuransi dari klaim-klaim yang terjadi.

\section{DAFTAR PUSTAKA}

1. Cai, J. \& Tan, K. S., Optimal Retention for a Stop Loss Reinsurance Under The VaR and CTE Risk Measures, Department of Statistics and Actuarial Science. University of Waterloo, Ontario, 2007.

2. Hartono, S. R., Hukum Asuransi dan Perusahaan Asuransi, Edisi 1, Sinar Grafika, Jakarta, 1997.

3. Kementrian Negara Koperasi dan Usaha Kecil dan Menengah Republik Indonesia, Optimalisasi Manfaat Asuransi dalam Peningkatan Akses Pembiayaan Bagi Usaha Mikro, Kecil, Menengah dan Koperasi (UMKM-K), Deputi Bidang Pembiayaan, Jakarta, 2009.

4. _ Koran Otomotif, 2010.

5. Lester., 1987, Tutorial Subjek-210, Introduction, diakses 2 Maret 2010, http://s2informatics.files.wordpress.com.

6. Pracoyo, A., Studi Pengukuran Value At Risk Pada Distribusi Return Saham Yang Bersifat Leptokurtosis : Studi kasus : Saham ASII, ISAT, SMDR dan UNVR, 2009, http://jurnal.dikti.co.id.

7. Preda, V., Dedu, S., \& Ciumara, R., An Unfied Approach For Retensi optimal in a Stop Loss Reinsurance Under The VaR and CTE Risk Measures, The XIII International Conference, Vilnius, Lithuania, 30 Juni-3 Juli 2009.

8. Rahmany, A. F., Peraturan Ketua Badan Pengawas Pasar Modal dan Lembaga Keuangan, Departemen Keuangan Republik Indonesia, Jakarta, 2008.

9. Utomo, T., \& Djunedi, P., Analisis Beberapa Metode Reasuransi, Kajian Ekonomi dan Keuangan, 2005, Vol. 9, No. 1.

10. Sartono, R.A. dan Setiawan, A.A., VaR Portfolio Optimal: Perbandingan Antara MetodeMarkowitz Dan Mean Absolute Deviation, Jurnal Siasat dan Bisnis, April 2006, Vol. 11, no. 1: 37-50. 